\title{
ОригинальныЕ Статьи
}

\section{ORIGINAL PAPERS}

\section{КОМПЛЕКСООБРАЗОВАНИЕ КАНАМИЦИНА С СУАЬФАТОМ АЦЕТАТОМ ЦЕААЮАОЗЫ: ПЕРСПЕКТИВНЫЙ ПУТЬ ОТ ИНЪЕКЦИОННОЙ АЕКАРСТВЕННОЙ ФОРМЫ К ПЕРОРААЬНОЙ}

\author{
T. А. САВИЦКАЯ ${ }^{1)}$, Е. А. ШАХНО ${ }^{1)}$, И. П. БОСЬКО ${ }^{1)}$, ВАДИМ Э. МАТУЛИС ${ }^{1)}$, \\ Н. А. МЕЛЕХОВЕЦ ${ }^{2)}$, Д. Д. ГРИНШПАН ${ }^{2)}$, О. А. ИВАШКЕВИЧ \\ ${ }^{1)}$ Белорусский государственный университет, пр. Независимости, 4, 220030, г. Минск, Беларусь \\ ${ }^{2)}$ Научно-исследовательский институт физико-химических проблем, \\ ул. Ленинградская, 14, 220006, г. Минск, Беларусь
}

\section{Образец цитирования:}

Савицкая ТА, Шахно ЕА, Босько ИП, Матулис Вадим Э, Мелеховец НА, Гриншпан ДД, Ивашкевич ОА. Комплексообразование канамицина с сульфатом ацетатом целлюлозы: перспективный путь от инъекционной лекарственной формы к пероральной. Журнал Белорусского государственного университета. Химия. 2021;1:3-20 (на англ.). https://doi.org/10.33581/2520-257X-2021-1-3-20

\section{For citation:}

Savitskaya TA, Shakhno EA, Bosko IP, Matulis Vadim E, Melekhovets NA, Grinshpan DD, Ivashkevich OA. Kanamycin complexation with cellulose acetate sulphate: a promissing way from injectable to oral form of antibiotic. Journal of the Belarusian State University. Chemistry. 2021;1:3-20. https://doi.org/10.33581/2520-257X-2021-1-3-20

\section{Ав тор ы:}

Татьяна Александровна Савицкая - кандидат химических наук; профессор кафедры физической химии, заместитель декана по научной работе химического факультета.

Екатерина Александровна Шахно - аспирантка кафедры физической химии химического факультета. Научный руководитель - Т. А. Савицкая.

Иван Павлович Босько - студент химического факультета. Вадим Эдвардович Матулис - доцент кафедры неорганической химии химического факультета.

Наталья Анатольевна Мелеховец - младший научный сотрудник лаборатории растворов целлюлозы и продуктов их переработки.

Дмитрий Давидович Гриншпан - доктор химических наук; заведующий лабораторией растворов целлюлозы и продуктов их переработки.

Олег Анатольевич Ивашкевич - академик НАН Беларуси, доктор химических наук; главный научный сотрудник.

\section{Authors:}

Tatsiana A. Savitskaya, PhD (chemistry); professor at the department of physical chemistry and deputy dean for science, faculty of chemistry.

savitskayata@bsu.by

Ekaterina A. Shakhno, postgraduate student at the department of physical chemistry, faculty of chemistry.

schahnoea@gmail.com

Ivan P. Bosko, student at the faculty of chemistry.

vanya384@mail.ru

Vadim E. Matulis, associate professor at the department of inorganic chemistry, faculty of chemistry.

matulisvad@gmail.com

Natallia A. Melekhovets, junior researcher at the laboratory of cellulose solutions and products of their treatment.

melekhovets.na@gmail.com

Dmitry D. Grinshpan, doctor of science (chemistry); head of the laboratory of cellulose solutions and products of their treatment.

grinshpan@mail.ru

Oleg A. Ivashkevich, academician of the National Academy of Science of Belarus, doctor of science (chemistry); chief researcher.

ivashkevicho@bsu.by 
Нерастворимые в воде полиэлектролитные комплексы сульфата ацетата целлюлозы в форме натриевой соли (Na-САЦ) и аминогликозидного антибиотика (АБ) канамицина (КАН) были получены смешением водных растворов компонентов. Состав комплексов определялся кислотностью среды и порядком смешения. Показано, что увеличение количества целлобиозных единиц Na-САЦ на моль АБ коррелирует со снижением значения рН. Образование комплекса исследовали методами инфракрасной фурье-спектроскопии, термического анализа, рентгеноструктурного анализа, лазерной дифракции, анализа траектории движения наночастиц и сканирующей электронной микроскопии. Квантово-химическое исследование относительной стабильности протонированных форм КАН в водном растворе было выполнено для определения предпочтительных центров протонирования молекулы КАН. Значения $\mathrm{pK}_{\mathrm{a}}$ для КАН рассчитывались с помощью метода изодесмических реакций. Структуры и энергия связи для димера КАН и комплекса КАН - САЦ также исследованы квантово-химическими методами. Выявлено, что сам комплекс Na-САЦ - КАН, иммобилизованный на активированном угле, демонстрирует in vitro в два раза большую антибактериальную активность в сравнении со стандартной (инъекционной) формой КАН против Mycobacterium tuberculosis и может быть рекомендован для клинических испытаний in vivo как новая форма аминогликозида АБ для перорального применения.

Ключевые слова: туберкулез; канамицин; сульфат ацетат целлюлозы; комплекс; активированный уголь; пероральная лекарственная форма.

\title{
KANAMYCIN COMPLEXATION WITH CELLULOSE ACETATE SULPHATE: A PROMISSING WAY FROM INJECTABLE TO ORAL FORM OF ANTIBIOTIC
}

\author{
T. A. SAVITSKAYA , E. A. SHAKHNO a , I. P. BOSKO ${ }^{\text {a }, V A D I M ~ E . ~ M A T U L I S ~}{ }^{\text {, }}$ \\ N. A. MELEKHOVETS ${ }^{\mathrm{b}}$, D. D. GRINSHPAN ${ }^{\mathrm{b}}$, O. A. IVASHKEVICH ${ }^{\mathrm{b}}$ \\ ${ }^{a}$ Belarusian State University, 4 Niezaliežnasci Avenue, Minsk 220030, Belarus \\ ${ }^{\mathrm{b}}$ Research Institute for Physical Chemical Problems, Belarusian State University, \\ 14 Lieninhradskaja Street, Minsk 220006, Belarus \\ Corresponding author: N. A. Melekhovets (melekhovets.na@gmail.com)
}

\begin{abstract}
Water-insoluble polyelectrolyte complexes of cellulose acetate sulphate in the form of sodium salt (Na-CAS) and aminoglycoside antibiotic (AB) kanamycin (KAN) were obtained by mixing of the components aqueous solutions. The composition of the complexes was determined in accordance with the medium $\mathrm{pH}$ and mixing order. The increase of $\mathrm{Na}-\mathrm{CAS}$ cellobiose units per mole of $\mathrm{AB}$ has been shown to correlate with the decrease of $\mathrm{pH}$ value. The complex formation was studied by Fourier transform infrared spectroscopy, thermal analysis, X-ray analysis, laser diffraction, motion trajectory of nanoparticles analysis and scanning electron microscopy. Quantum-chemical study of the relative stability of the protonated forms of KAN in aqueous solution was performed to determine the preferred protonation sites of KAN molecule. The $\mathrm{pK}_{\mathrm{a}}$ values of KAN were calculated by means of isodesmic reactions method. The structures and binding energy for the KAN dimer and the KAN - CAS complex were also investigated by quantum-chemical methods. Na-CAS - KAN complex itself and immobilised on the activated carbon was shown to demonstrate in vitro two times antibacterial activity of the standard (injectable) form of KAN against Mycobacterium tuberculosis. It can be recommended for in vivo clinical trials as a new form of aminoglycoside $\mathrm{AB}$ for oral administration.
\end{abstract}

Keywords: tuberculosis; kanamycin; cellulose acetate sulphate; complex; activated carbon; oral dosage form.

\section{Introduction}

Taking a heavy toll on the world, tuberculosis (TB) as an infectious disease was named among the 2016's top 10 causes of death worldwide. In 2018, the first-ever UN General Assembly high-level meeting on tuberculosis endorsed a global strategy to accelerate efforts in ending TB [1]. Along with social-economic determinants, the main risk factors for TB include prolonged treatment and difficulties associated with chemotherapy. TB treatment usually involves the repeated continuous administration of large doses of different drugs, which leads, especially in the case of parenteral use, to various side effects. Addressing these issues requires improvement of already existing drugs formulation as well as the development of new anti-TB drugs with preference oral versus injectable forms.

Recently, many strategies based on new delivery materials have been developed to enhance the antibacterial efficacy and comfort taking of commonly used TB antibiotics. For example, dry powder aminoglycoside 
antibiotic $(\mathrm{AB})$ aerosol products were proposed for inhaled therapy for TB [2], but there is a discussion in literature about safety and long-term effects of this therapy. The hydrophobic ion-pairing approach has been recently suggested as a chemical strategy to reversibly modify the properties of $\mathrm{AB}$. Using the hydrophobic ion-pairing in drug molecules containing ionisable groups, polar counter-ions are stoichiometrically replaced with lipophilic ones. The modification by lipoamino acid was described for aminoglycoside AB kanamycin [3]. The resulting ion-pairs improve drug permeability, allowing a better systemic (e. g., intestinal) adsorption and enhancing cellular uptake. At the same time, the modification by polymers, which is considered as a method creating new easy-to-use medications and ameliorating drug-induced allergic and toxicological reactions, is recently a subject of numerous research but still not implemented in anti-TB antibiotic design at the industrial level $[1 ; 4 ; 5]$.

Aminoglycosides are one of the first AB. Produced by Streptomyces kanamyceticus kanamycin (KAN) was discovered over 60 years ago but in spite of such a long history it remains the successful broad-spectrum antibacterial agent, in particular the important second-line $\mathrm{AB}$ in the standard treatment regimen for multi-drug resistant TB. It exhibits the bactericidal action towards the majority of gram-positive and gram-negative microorganisms, and also the acid-resistant bacteria (including Mycobacterium tuberculosis) [3; 6]. Its irreversible binding to mRNA decodifying region of the bacterial ribosome 30S subunit allows the inhibition of the protein synthesis [7].

KAN is used in the form of mono- or disulphates intravenously and intramuscularly, since it is practically not absorbed from the gastrointestinal tract (GIT): absorption capacity is less than $1 \%$ in the absence of mucosa damage [2]. The oral application route of KAN in capsules, tablets or syrup is used pre-eminently for local sterilisation of the gastric cavity before operative treatment [6]. Therefore, the replacement of the injections with solid oral dosage forms will make it possible to improve and substantially simplify the treatment regimen for tuberculosis patients, making it less traumatic and invasive.

The focus of the present study was to modify KAN sulphate into new oral drug form through its converting into the polymer salt with cellulose acetate sulphate in the form of sodium salt (Na-CAS) as counter-ion and by further immobilization of this ionic-pair on the activated carbon (AC).

According to [8-10] the dimerisation and higher clustering of aminoglycoside $\mathrm{AB}$ is known. However, literature on aggregation of KAN or related aminoglycosides is extremely sparse, both on the experimental and on the theoretical side. It is reported that KAN aggregates into bare dimers and dimers with certain physiological cations, preferentially sodium one [8]. Covalent linked dimers have been obtained by using a «tether» and studied [9]. Formation of long fibers as a linear noncovalent assembly of KAN molecules on negatively charged surfaces was determined as well [10].

The experimental study included the synthesis of KAN and Na-CAS complexes, the establishing of the components concentration and $\mathrm{pH}$ medium impact on the complexes composition, complexes solubility and dispersion, bacteriological activity in parallel with theoretical research such as quantum-chemical calculations, molecular dynamics simulations of KAN protonation, dimerisation and complexation with Na-CAS.

\section{Materials and methods}

Materials. KAN sulphate (2-(aminomethyl)-6-[4,6-diamino-3-[4-amino-3,5-dihydroxy-6-(hydroxymethyl) oxan-2-yl] oxy-2-hydroxycyclohexyl] oxyoxane-3,4,5-triol;sulphuric acid) in an injectable powder form was purchased from Kyivmedpreparat (Ukraine) in the form of acid sulphate, KAN base - from North China Pharmaceutical (China). We took into account that as commonly occurs with natural products, this antibiotic turned out to be a complex of several closely related substances: a major component, kanamycin A (usually designated as kanamycin), and two minor variants (less than $5 \%$ ), kanamycin B and C [11]. However, we considered that $\mathrm{AB}$ behaviour in the complexation process determines mainly by kanamycin $\mathrm{A}$ and this form was used in quantum-chemical calculations.

Na-CAS (poly-( $1 \beta \rightarrow 4)-(2-O-a c e t y l-6$-sulpho- $D$-glucopyranose)) was homogeneously synthesised according to [12] and had viscosity average molecular weight $\left(M_{\eta}\right) 36000,(14.4 \pm 0.1) \%$ of combined acetic acid and (32.0 \pm 0.1$) \mathrm{wt}$. $\%$ of combined sulphuric acid. Cellobiose unit was chosen as a configuration repeated unit of Na-CAS (fig. 1) in spite of the fact that some authors consider glucose unit but as chemical composition repeated unit [13] (the molecular weight of cellobiose mole-link was 574) and polymer concentration was expressed in the moles of these units.

AC in the form of a fine powder of birch activated charcoal from Sorbent JSC (Russia) was used for immobilisation of a complex when tablets prepared. $\mathrm{AC}$ was considered as a carrier for $\mathrm{AB}$ - polymer complex in the design of the solid dosage form. 
$a$

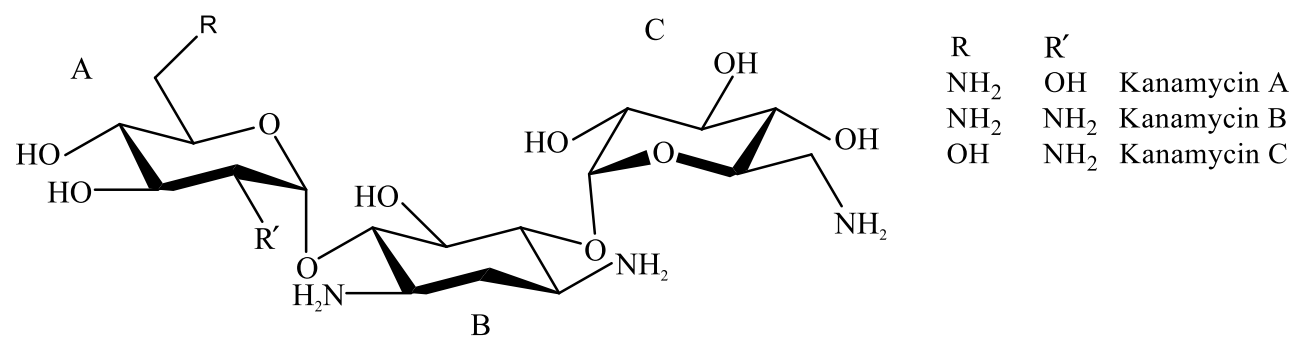

$b$

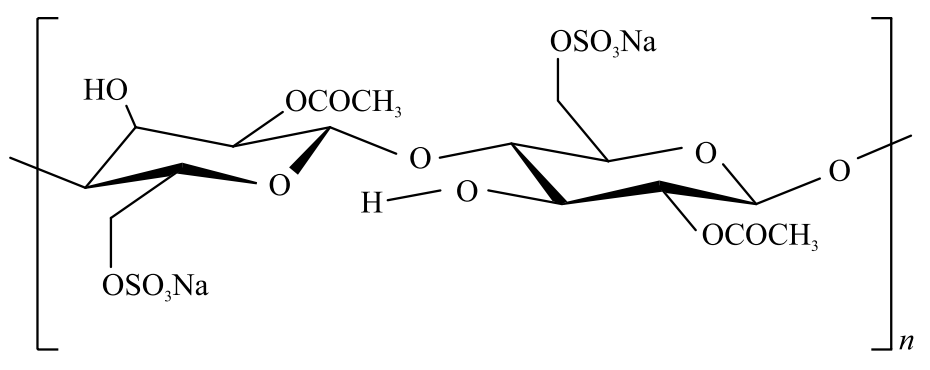

Fig. 1. Structural formulas of KAN (a) and Na-CAS repeated unit (b)

Formation of Na-CAS and KAN complex. $\mathrm{AB}$ and polymer solutions of appropriate concentrations were prepared and mixed in molar ratio between $\mathrm{AB}$ and polymer from $1: 8$ to $8: 1$, changing mixing order and $\mathrm{pH}$ medium. Distilled water, buffer solutions with $\mathrm{pH}$ 2.0, 6.0 and 7.5 were used. Before mixing, the solutions were filtered through $0.45 \mu \mathrm{m}$ pore size membrane. The composition of obtained complexes was determined using colloid titration technique on CPC-3-01 photoelectric colorimeter (ZOMZ, Russia) at $540 \mathrm{~nm}$ wavelength [14]. This technique is based on the system ability to scatter light when a dispersion of insoluble particles is formed. Under the direct complex synthesis, polymer solutions with a concentration of $10^{-3} \mathrm{~mol} / \mathrm{dm}^{3}$ were titrated by the solutions of $\mathrm{AB}$ with a concentration of $10^{-2} \mathrm{~mol} / \mathrm{dm}^{3}$ by sequentially adding $5 \mu \mathrm{L}$ portions of the solution under stirring until the growth of the solid ceased, which was indicated by reaching constant optical density. Optical density $D$ was measured $1 \mathrm{~min}$ after the addition of each portion of titrant. Using the inverse mixing order, solution of $\mathrm{AB}$ with a concentration of $10^{-3} \mathrm{~mol} / \mathrm{dm}^{3}$ was titrated by the solution of polymer with a concentration of $10^{-2} \mathrm{~mol} / \mathrm{dm}^{3}$ by sequentially adding $5 \mu \mathrm{L}$ portions of the solution. The content of $\mathrm{AB}$ in the complex was determined by chemical analysis (Kjeldahl technique). All experiments were performed at ambient temperature.

Fourier transform infrared spectroscopy (FTIR) and scanning electron microscopy (SEM). Samples for FTIR and SEM were prepared in the form of coevaporates obtained by applying Na-CAS - KAN complex particles suspensions. The above-mentioned suspensions were obtained by mixing $10 \mathrm{wt}$ \% solutions of the components in a ratio corresponding to the complex composition, then pouring on a glass substrate, followed by evaporating water in air at the ambient temperature. The FTIR spectra were recorded on a Nicolet iS10 FTIR spectrometer (Thermo Fisher Scientific, USA) through 46 scanning at a $0.5 \mathrm{~cm}^{-1}$ resolution. The morphology of the films surface after deposition of gold (a Emitech K550 instrument was employed) was examined on a LEO-1420 scanning electron microscope (Carl Zeiss, Germany) at magnifications from 500× to $20000 \times$.

Thermal analysis. Thermal analysis was carried out through thermogravimetric (TG), differential thermogravimetric analysis (DTG), differential scanning calorimetry (DSC) on a thermal analyser STA 449 Upiter (Netzsch, Germany). Samples of the complexes in the form of powders were obtained by mixing components solutions, precipitates filtration through the paper filter and under-vacuum drying. Analysis was performed at a heating rate of $10 \mathrm{~K} / \mathrm{min}$ in the temperature range $303-600 \mathrm{~K}$ with nitrogen gas flow of $25 \mathrm{~cm}^{3} / \mathrm{min}$ and 8-10 mg samples.

Laser diffraction method. The particles hydrodynamic size in the solutions of Na-CAS and in the sols of its complexes with KAN, obtained by mixing of solutions with Na-CAS concentration of $2 \cdot 10^{-5} \mathrm{~mol} / \mathrm{dm}^{3}$ and $\mathrm{AB}$ concentration corresponding to the compositions of the complexes, were estimated using laser diffraction method on a Zetasizer nano ZS device (Malvern, UK) at the temperature $298 \mathrm{~K}$. The kinetics of the complex particles growth was evaluated by a Mastersizer 3000 laser particle size analyser (Malvern) using a wet dispersion unit with a measuring vessel volume of $120 \mathrm{~cm}^{3}$ at a rotation speed of $1500 \mathrm{~min}^{-1}$. The formation of complex particles dispersions resulted directly in the vessel by adding of the polymer solution $\left(0.02 \mathrm{~mol} / \mathrm{dm}^{3}\right)$ to the $\mathrm{AB}$ solution with the concentration of $0.002 \mathrm{~mol} / \mathrm{dm}^{3}$ and by different mixing order. 
The particles size distribution was also estimated by the analysis of motion trajectory of nanoparticles on a Nanosight LM0 multiparametric analyser of nanoparticles (Nanosight Ltd., UK) in the HS - BF configuration (Andor Luca high-sensitivity video camera; a semiconductor laser with a wavelength of $405 \mathrm{~nm}$ and a power of $45 \mathrm{~mW}$ ).

X-ray diffraction analysis (XRD). Powders of KAN, Na-CAS and their complex XRD analysis was carried out on a Drone 3.0 X-ray diffractometer (Bourevestnik, Russia), $\mathrm{Cu} K_{\alpha}$ radiation, at an accelerating voltage of $50 \mathrm{kV}$. Data were systematically collected from $23^{\circ}$ to $3^{\circ}$ in $2 \theta$ with a scan speed of $2 \%$ min in $2 \theta$ and a step size of $0.05^{\circ}$.

Bacteriological tests. The content of the bacteriologically active $\mathrm{AB}$ form was determined with the bioassay technique on agar plates. Tablet forms of the water-insoluble complexes immobilised on the activated carbon sorbent were obtained by triturate method with the laboratory setup, followed by drying at $T=(303 \pm 1) \mathrm{K}$ in an air flow to a constant weight. Tests to determine the drug susceptibility of M. tuberculosis to the action of this new KAN pharmaceutical form were carried out by the absolute concentration method using Löwenstein - Jensen medium [15].

Computational details. Protonation of KAN A in aqueous solution. The starting geometry of KAN A was taken from the Cambridge Crystallographic Data Centre ${ }^{1}$. The geometrical parameters of KAN A molecule and corresponding protonated structures were fully optimised using CAM-B3LYP/6-31G(d) level of theory [16]. Our previous investigations showed that this computational level provides good agreement of the calculated geometries of heterocyclic compounds with the experimental data [17]. The optimised geometries were used for single point energy calculation using CAM-B3LYP/6-311+G(d,p) level of theory. The solvent effects were evaluated using the polarised continuum model [18] with the default parameters for water.

The $\mathrm{pK}_{\mathrm{a}}$ values were calculated by means of isodesmic reactions method. We considered the following isodesmic reaction:

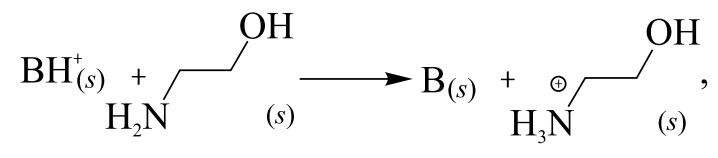

where B is kanamycin A molecule.

The isodesmic reaction Gibbs energy in an aqueous solution was calculated using the following equation:

$$
\Delta_{r} G_{s}=\sum_{\text {products }} G_{s}-\sum_{\text {reactants }} G_{s} .
$$

Further, it can be proved that

$$
\mathrm{pK}_{\mathrm{a}}(\mathrm{B})=\mathrm{pK}_{\mathrm{a}}(\text { ethanolamine })+\frac{\Delta_{r} G_{s}}{R T} \frac{1}{\ln 10},
$$

where $\mathrm{pK}_{\mathrm{a}}$ (ethanolamine) is equal 9.5 [19].

Our previous studies have showed that this computational method gave the calculated $\mathrm{pK}_{\mathrm{a}}$ values for heterocyclic compounds which were consistent with the experimental data [20]. Obviously, the KAN A molecule and the corresponding protonated structures has many different conformations. The data below refer to the most stable ones.

Binding energy of KAN dimer and KAN - CAS complex. By virtue of the fact that complex composition corresponds to one mole of KAN per two CAS glucose mole-links we used cellobiose unit as a polymer chain fragment. The semi-empirical GFN-xTB method [21] has been used for the conformational search to obtain the initial structures for global minimum searching. The resulting structures were ranked by energy, and the geometry of the ten lowest energy structures have been optimised using PBEh-3c/def2-mSVP method [22], which is computationally cheap and shows good performance for non-covalent interaction energies in complexes. The most stable structures were then optimised on the wB97XD/6-31G(d) level of theory.

For both dimer and complex structures basis set superposition error (BSSE) was estimated and subtracted from energies of these structures. All the calculations have been carried out for isolated molecules (gas phase).

${ }^{1}$ The Cambridge Crystallographic Data Centre (CCDC) [Electronic resource]. URL: https://www.ccdc.cam.ac.uk/ (data of access: 20.06.2019). 
The binding energy of KAN dimer and KAN - CAS complex has been calculated using the following equations:

$$
\begin{gathered}
\Delta E_{\mathrm{d}}=E_{\mathrm{d}}-2 E_{\mathrm{m}}, \\
\Delta E_{\mathrm{c}}=E_{\mathrm{c}}-E_{\mathrm{m}}-E_{\mathrm{CAS}},
\end{gathered}
$$

where $E_{\mathrm{d}}, E_{\mathrm{m}}, E_{\mathrm{c}}, E_{\mathrm{CAS}}$ are the total energies of dimer, monomer, complex and CAS fragment respectively.

\section{Results and discussion}

Na-CAS and KAN aqueous solutions mixing results in the formation of insoluble hydrophobic product due to the co-operative interaction between functional groups of polyelectrolyte chain and $\mathrm{AB}$ molecules. The terms «complex of an antibiotic with a polymer» or «polymeric salt of an antibiotic» are used in literature to refer to similar substances [18].

Depending on the components solutions concentrations, the complex dispersion can be obtained as either a sol $\left(\mathrm{c}<10^{-5} \mathrm{~mol} / \mathrm{dm}^{3}\right)$ or suspension $\left(\mathrm{c}>10^{-5} \mathrm{~mol} / \mathrm{dm}^{3}\right)$, the optical densities of which are proportional to the size and concentration of the complex particles.

$a$

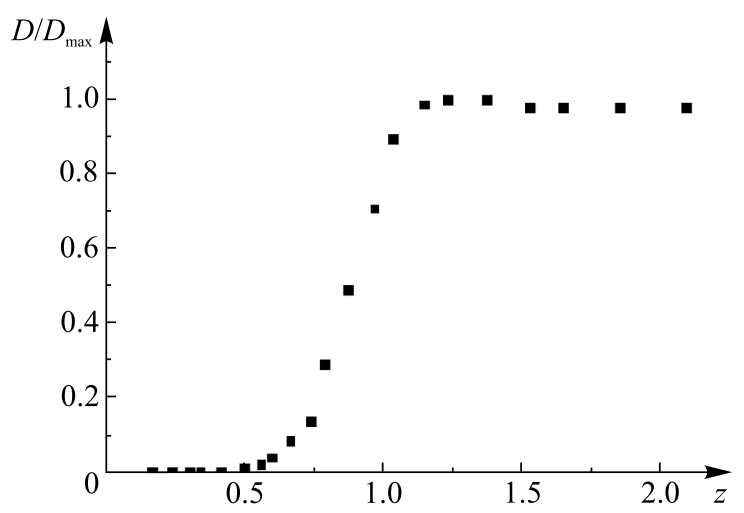

$b$

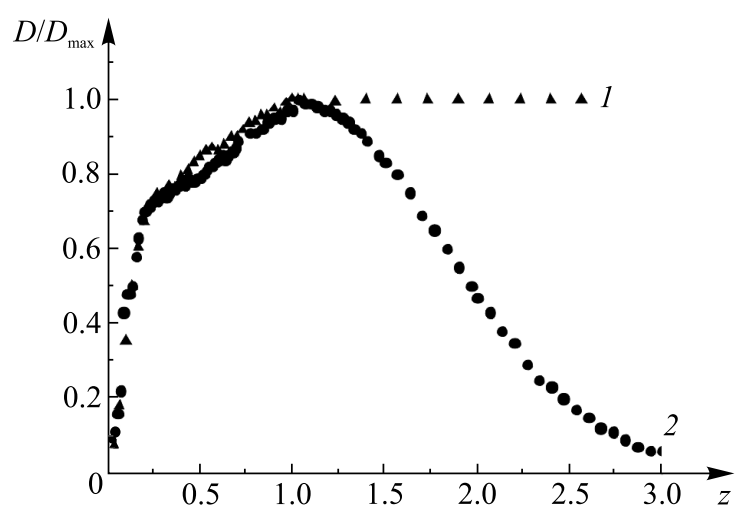

Fig. 2. Colloid titration curves: $a$ - for Na-CAS solution by KAN solution; $b$ - for KAN solution by $\mathrm{H}_{2} \mathrm{O}$ after complex formation (1) and by KAN solution (2) at $\mathrm{pH} 6.0$. $z=[\mathrm{Na}-\mathrm{CAS}]:[\mathrm{KAN}]$

As follows from fig. 2, the composition of the complex corresponds to [Na-CAS] : $[\mathrm{KAN}]=2.4: 1.0$ and $[\mathrm{Na}-\mathrm{CAS}]:[\mathrm{KAN}]=2.0: 1.0$ at direct and inverse titration respectively.

There are four possible protonation sites in the KAN molecule (nitrogen atoms of four amino groups). The protonation of $\mathrm{AB}$ molecules affects their conformation and interaction with target biomolecules. For this reason, data on the thermodynamics of aminoglycoside protonation together with exact assignment of the protonation sites are necessary for the interpretation of their activity. According to the data [23] the stepwise protonation constants $\mathrm{pK}_{\mathrm{a}}$ of $\mathrm{KAN}$ are 9.16 (C6' (ring A)), 8.27 (C1 (ring B)), 7.52 (C3" (ring C)) and 6.28 (C3 (ring B)). In this work, we performed a quantum-chemical study of the relative stability of the protonated forms of KAN in aqueous solution to determine the preferred protonation sites. Figure 3 represents the optimised structures of four KAN A ions with different protonated amino groups.

Table 1 lists the relative (the smallest value has been taken as zero) Gibbs free energies of the ions. The results of quantum chemical calculations show that the stability of protonated forms of KAN A decreases as follows

$$
\mathrm{C}^{\prime}(\operatorname{ring} \mathrm{A}) \sim \mathrm{C} 1(\operatorname{ring} \mathrm{B})>\mathrm{C} 3(\operatorname{ring} \mathrm{B})>\mathrm{C} 3{ }^{\prime \prime}(\operatorname{ring} \mathrm{C}) \text {. }
$$

The results obtained agree with the experimental data [23] on the protonation sequence of the amino groups of KAN A molecule in aqueous solution:

$$
\mathrm{C}^{\prime} \text { ( } \text { (ring A) } \rightarrow \mathrm{C} 1 \text { (ring B) } \rightarrow \mathrm{C} 3 \text { " (ring C) } \rightarrow \mathrm{C} 3 \text { (ring B). }
$$

The $\mathrm{pK}_{\mathrm{a}}$ values of the deprotonation for each amino group of KAN A ions were calculated and compared with experimental data [23] (table 2). The calculation results agree with experimental data. 
Ion-1

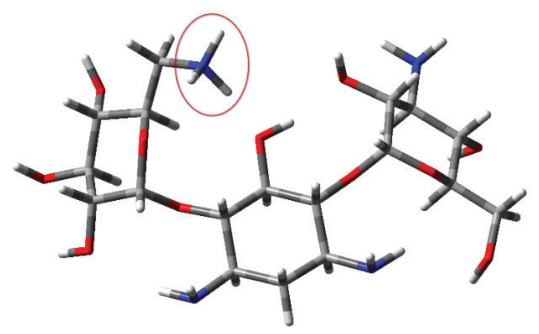

Ion-3

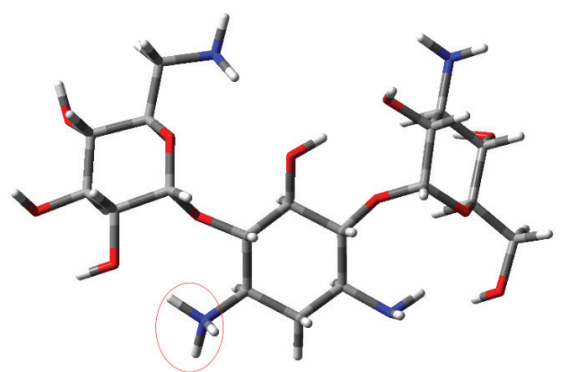

Ion-2

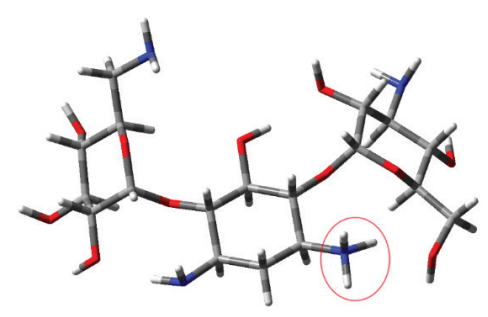

Ion-4

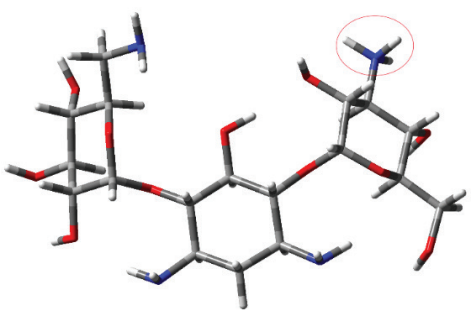

Fig. 3. Optimised structures for KAN A ions with different protonated amino group: ion-1 - $\mathrm{C}^{\prime}$ (ring A); ion-2 - $\mathrm{C} 1$ (ring $\left.\mathrm{B}\right)$; ion-3 - C3 (ring B); ion-4 - C3" (ring C)

Table 1

Calculated the relative Gibbs free energies of KAN A ions with different protonated amino groups

\begin{tabular}{|c|c|c|}
\hline Ion & Site of protonation (ring and number of carbon atom) & $\Delta G, \mathrm{~kJ} / \mathrm{mol}$ \\
\hline Ion-1 & $\mathrm{A}, \mathrm{C} 6^{\prime}$ & 2.13 \\
\hline Ion-2 & $\mathrm{B}, \mathrm{C} 1$ & 0.00 \\
\hline Ion-3 & $\mathrm{B}, \mathrm{C} 3$ & 8.57 \\
\hline Ion-4 & $\mathrm{C}, \mathrm{C} 3^{\prime \prime}$ & 16.47 \\
\hline
\end{tabular}

Table 2

Calculated and experimentally determined $\mathrm{pK}_{\mathrm{a}}$ value of KAN A

\begin{tabular}{|c|c|c|}
\hline $\begin{array}{c}\text { Site of protonation } \\
\text { (ring and number of carbon atom) }\end{array}$ & CAM-B3LYP/6-31G(d)/6-311+G(d,p) & $\begin{array}{c}\text { Experimental } \\
\text { data }\end{array}$ \\
\hline A, C6' & 9.61 & 9.16 \\
\hline B, C1 & 9.99 & - \\
\hline B, C3 & 8.48 & - \\
\hline C, C3" & 7.10 & - \\
\hline
\end{tabular}

Thus, the preferred protonation sites of KAN in aqueous solution were determined: amino groups at the C6' (ring A) and C1 (ring B). Further, this will be taken into account when calculating the structure of the $\mathrm{Na}-\mathrm{CAS}$ - KAN complex.

Gradual protonation of KAN base caused by adding calculated amounts of hydrochloric acid to KAN aqueous solution followed by the rearrangement of $\mathrm{AB}$ hydrogen bonds system. Table 3 shows that there is a tendency to shift bands in FTIR spectra of KAN solutions with different concentrations of $\mathrm{HCl}$ but to a certain limit. The position of the bands ceases to change after the tetra protonated KAN is formed. For example, $\mathrm{OH}$ group of one of the terminal ring involved in the hydrogen bond with $\mathrm{NH}_{2}$ group is responsible according 
to [9] for the peak at $3250 \mathrm{~cm}^{-1}$ in a dimer, that essentially corresponds to the monomer peak at $3338 \mathrm{~cm}^{-1}$. In our case there was $3258.9 \mathrm{~cm}^{-1}$ peak in the initial solution. After the protonation of all $\mathrm{NH}_{2}$ group it places at $3100.0 \mathrm{~cm}^{-1}$.

Bands position in FTIR spectra for 5 wt. \% KAN base aqueous solutions with different amounts of $\mathrm{HCl}$ for amino groups protonation

\begin{tabular}{|l|c|c|c|c|c|}
\hline \multicolumn{1}{|c|}{ Sample } & \multicolumn{5}{c|}{ Bands position, $\mathrm{cm}^{-1}$} \\
\hline KAN acid sulphate dry powder & 3142.1 & 1614.7 & 1521.1 & 1022.6 & - \\
\hline $\begin{array}{l}\text { Aqueous solution of KAN base } \\
\text { without HCl }\end{array}$ & 3258.9 & 1634.8 & 1531.1 & 1057.6 & - \\
\hline $\begin{array}{l}\text { Aqueous solution of KAN base with } \\
\text { HCl equivalent for 2 amino groups }\end{array}$ & 3171.0 & 1624.9 & 1523.3 & 1023.6 & - \\
\hline $\begin{array}{l}\text { Aqueous solution of KAN base with } \\
\text { HCl equivalent for 3 amino groups }\end{array}$ & 3170.0 & 1613.6 & 1509.9 & 1023.3 & 863.7 \\
\hline $\begin{array}{l}\text { Aqueous solution of KAN base with } \\
\text { HCl equivalent for 4 amino groups }\end{array}$ & 3100.0 & 1609.6 & 1506.5 & 1022.0 & 861.5 \\
\hline $\begin{array}{l}\text { Aqueous solution of KAN base with } \\
\text { HCl equivalent for 6 amino groups }\end{array}$ & 3100.0 & 1609.1 & 1505.9 & 1022.7 & 860.6 \\
\hline 0.1 mol/L HCl (pH 1.0) & 3100.0 & 1605.7 & 1505.1 & 1040.1 & 858.7 \\
\hline
\end{tabular}

Simultaneously, the increasing of Na-CAS mole-links per KAN mole takes place as shown in fig. 4. It demonstrates that the more the acidity of the medium, the more colloidal titration curves shift to the right along the abscissa axis. This means that $\mathrm{NH}_{2}$ group protonation causes an increase in the amount of Na-CAS molelinks connected with KAN mole.

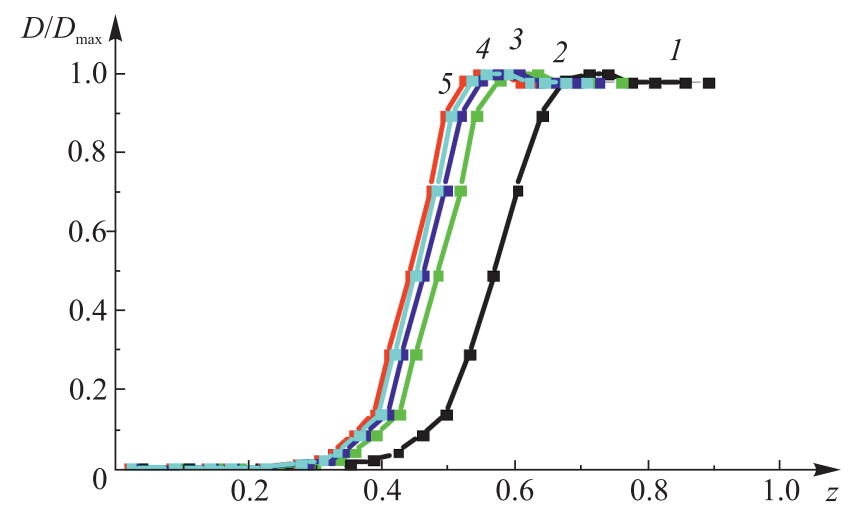

Fig. 4. Colloid titration curves of Na-CAS aqueous solution by the KAN base solutions ( 1 ) with different amount of $\mathrm{HCl}$ added for the protonation of 1,2,3 and 4 amino groups respectively $2,3,4$ and 5 . $z=[\mathrm{Na}-\mathrm{CAS}]:([\mathrm{KAN}]+[\mathrm{Na}-\mathrm{CAS}])$

Turning back to fig. 2, one can see that the composition of the complex in the medium of acetate buffer (pH 6.0) corresponds to a molar ratio of [KAN] : $[\mathrm{Na}-\mathrm{CAS}]=1.0: 2.4$ at direct titration. Figure $2, a$, shows that adding of $\mathrm{AB}$ excess leads to a slight decrease in turbidity due to the hydrophilisation of the complex particles via binding of the extra amount of ionogenic KAN molecules, that are relatively small in size compared to polymer macromolecules. In the case of inverse titration, the curve maximum corresponds to a ratio KAN : Na-CAS $=1.0: 2.0$ with the observed decrease in optical density following by the addition of polymer solution to the resulting dispersion of the complex particles. In this case, the system becomes transparent, which can be attributed to the transition of the complex into the dissolved state due to hydrophilisation asso- 
ciated with the decrease in the number of contacts of the Na-CAS sulphate groups with the protonated KAN amino groups. The decrease in turbidity in such a circumstance is not caused by dilution, since, as follows from fig. $2, b$ (curve 1 ), when diluted with water, the optical density of the system does not change.

Table 4 data confirms that the decrease in turbidity is caused by the complex dissolution, rather than by its degradation. As can be seen from table 4 the size of the complex particles in hydrosol exceeds that of the particles in a solution of polymer itself with a concentration corresponding to its partial concentration in hydrosol. The excess amount of the polymer followed by the growth of particles size. At the same time, the size of the particles in the solutions of individual polymer falls down with a concentration that is typical for polyelectrolyte solutions behaviour. Attention is drawn to the fact that, when the [Na-CAS] : [KAN] molar ratio of $3.0: 1.0$ is achieved, the size of the complex particles practically stops changing, due to the saturation of the protonated amino groups, that are capable of interacting with the polymer. Figure 5 illustrates the particle size distribution for all these cases.

\section{Table 4}

\section{Average hydrodynamic diameter of the Na-CAS - KAN complex particles in hydrosols and Na-CAS supramolecular structures in aqueous solution estimated via laser diffraction method}

\begin{tabular}{|c|c|c|}
\hline \multirow{2}{*}{$\begin{array}{c}\text { Na-CAS }: \text { KAN } \\
\text { molar ratio }\end{array}$} & \multicolumn{2}{|c|}{ Average hydrodynamic diameter of the particles, nm } \\
\cline { 2 - 3 } & Hydrosol of Na-CAS - KAN complex & $\begin{array}{c}\text { Na-CAS solution with partial } \\
\text { concentration }\end{array}$ \\
\hline $1.0: 1.0$ & 350 & 250 \\
\hline $2.0: 1.0$ & 380 & 250 \\
\hline $3.0: 1.0$ & 395 & 235 \\
\hline $4.0: 1.0$ & 390 & 230 \\
\hline
\end{tabular}

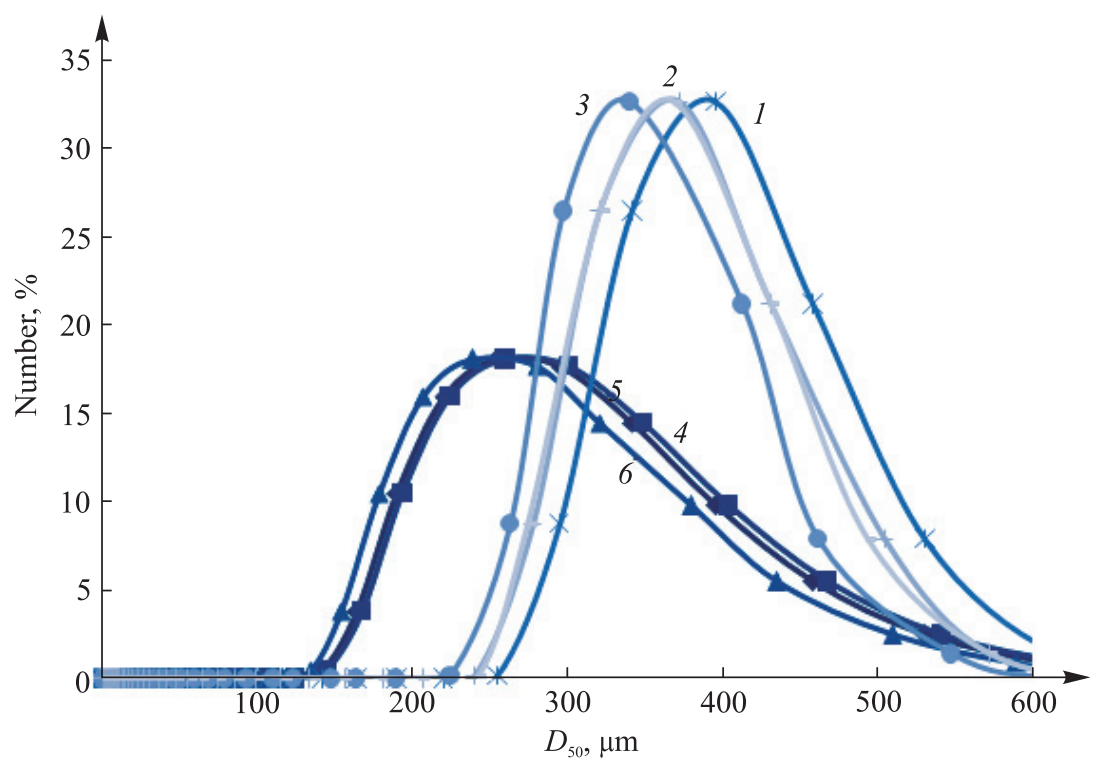

Fig. 5. Differential curves of particles hydrodynamic size distribution estimated via laser diffraction technique for hydrosols of

$\mathrm{Na}-\mathrm{CAS}$ - KAN complexes for different amount of Na-CAS moles per KAN mole: $1-1 ; 2-2 ; 3-3$ and for aqueous solutions of $\mathrm{Na}-\mathrm{CAS}$ with corresponding partial concentration $4,5,6$ respectively

Determination of Na-CAS - KAN complexes particle size in the dispersions, obtained through the blending of solutions with different concentrations, revealed that the higher the concentration of the solutions, the larger the particles size. For instance, with an increase in the concentration of the polymer solution from 0.02 to $0.16 \mathrm{~mol} / \mathrm{dm}^{3}$, the particle size increases from 20 to $45 \mu \mathrm{m}$. At the same time, direct titration produces lar- 
ger particles than the inverse titration, since the amino groups of the same AB molecule can, in the first case, interact with the sulphate groups belonging to different Na-CAS macromolecules, stitching them together. In the second case, the number of contacts of these complementary groups decreases. Indeed, with the reverse method of components solutions blending, the average particle size in the Na-CAS - KAN suspensions only reached $0.5 \mu \mathrm{m}$. As follows from fig. $6, a$, the kinetics of particle growth also depends on the method of the components solutions mixing. With the inverse method, particles of a finite size are formed immediately, whereas with the direct method, it takes at least $15 \mathrm{~min}$ to achieve a sizable growth. Figure $6, b$, illustrates the distribution of the particles for Na-CAS - KAN complexes.

$a$

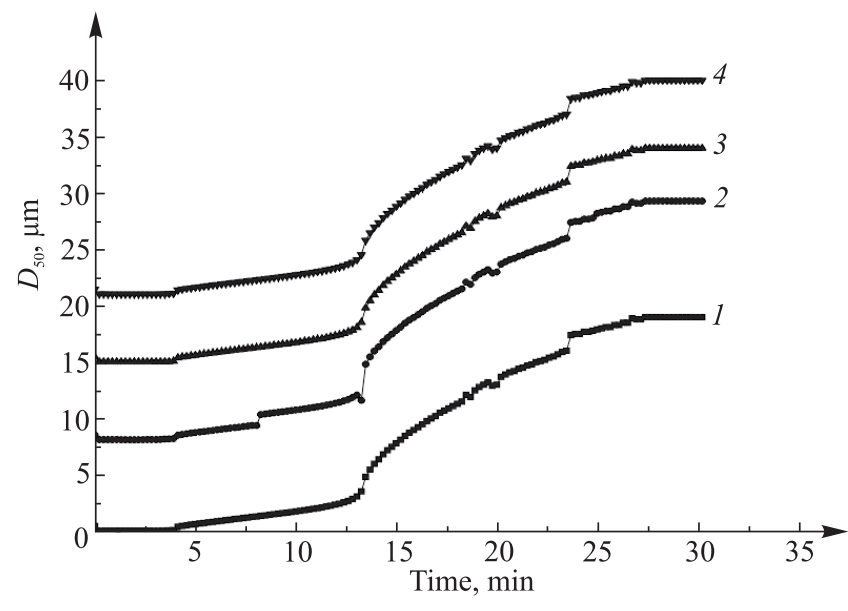

$b$

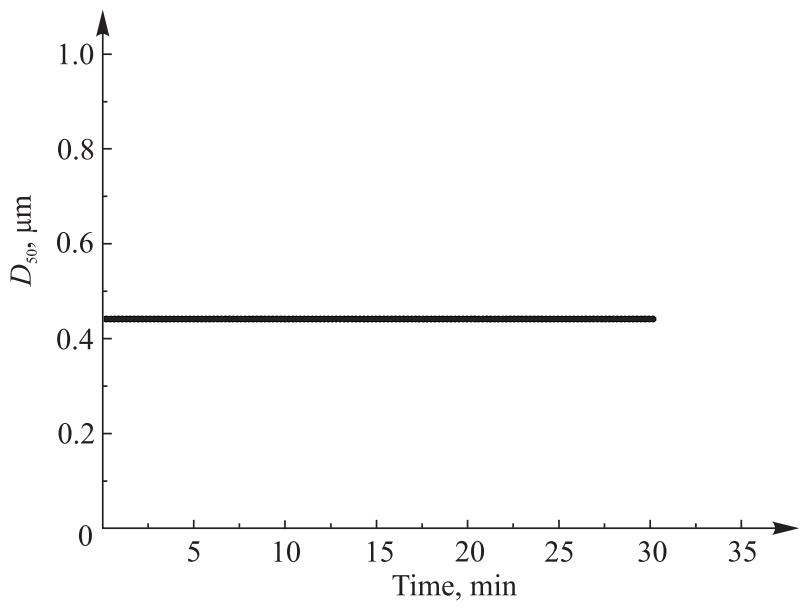

$c$

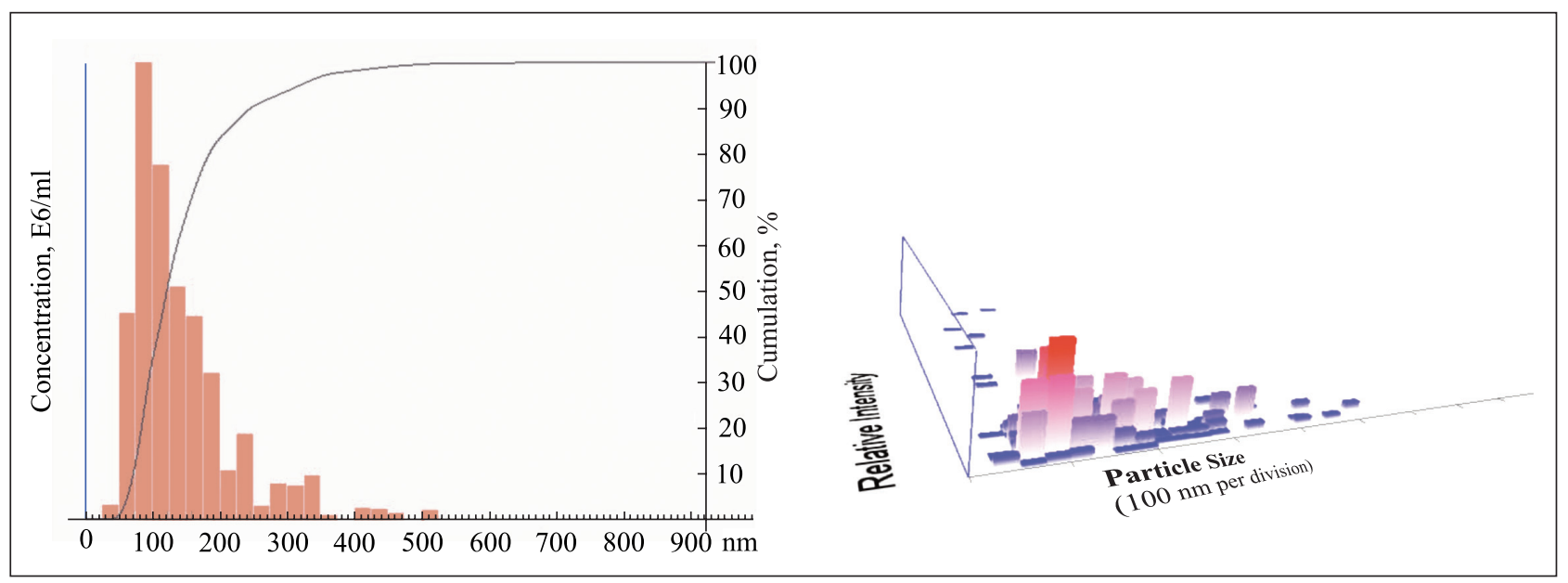

Fig. 6. Distribution of the particles for Na-CAS - KAN complexes: $a$ - kinetic curves of the particles size growth for Na-CAS - KAN suspensions under direct titration at the concentration of Na-CAS solutions $0.02 \mathrm{~mol} / \mathrm{dm}^{3}(1)$, $0.04 \mathrm{~mol} / \mathrm{dm}^{3}(2), 0.08 \mathrm{~mol} / \mathrm{dm}^{3}(3), 0.016 \mathrm{~mol} / \mathrm{dm}^{3}(4)$;

$b$ - inverse titration curve; $c$ - histogram of particle size distribution for hydrosol of Na-CAS - KAN complex $(b)$

obtained by the analysis nanoparticles motion trajectory respectively

Non-identical composition of the complex particles in the dependence of mixing order was confirmed by the agar diffusion test. It was held to determine the percentage of the bacteriologically active $\mathrm{AB}$ form in a complex and showed (table 5) that an inverse order of the components mixing results in almost $10 \mathrm{wt} . \%$ higher KAN content in the complex than a direct one. The elemental chemical analysis confirmed this result.

The visualisation of Na-CAS - KAN complex particles was carried out by the SEM technique (fig. 7). The evidence presented suggests that, after removing of the dispersion medium, the complex particles tend to form spherical aggregates with sizes ranging from 2 to $8 \mu \mathrm{m}$ for the direct mixing order, and less than $1 \mu \mathrm{m}$ for the inverse one. This morphological picture is similar to that one for Na-CAS film that we published earlier [12]. 
The content of the bacteriologically active $A B$ form

in Na-CAS - KAN complexes determined with the bioassay technique on agar plates and chemical analysis

\begin{tabular}{|l|c|c|}
\hline \multirow{2}{*}{ Complex preparation method } & \multicolumn{2}{|c|}{ KAN content, wt. \% } \\
\cline { 2 - 3 } & Bioassay technique & Chemical analysis \\
\hline Direct & $43,8 \pm 0,9$ & $47,6 \pm 0,1$ \\
\hline Inverse & $52,3 \pm 0,5$ & $49,2 \pm 0,1$ \\
\hline
\end{tabular}

Table 6

Bands position in FTIR spectra for individual components and their complex

\begin{tabular}{|l|c|c|c|c|c|}
\hline \multicolumn{1}{|c|}{ Composition } & \multicolumn{5}{c|}{ Band position, $\mathrm{cm}^{-1}$} \\
\hline KAN & 3150 & 1618 & 1529 & - & - \\
\hline Na-CAS & 3440 & 1637 & - & 1225 & 799 \\
\hline Complex Na-CAS - KAN & 3380 & 1631 & 1536 & 1220 & 798 \\
\hline
\end{tabular}

$a$

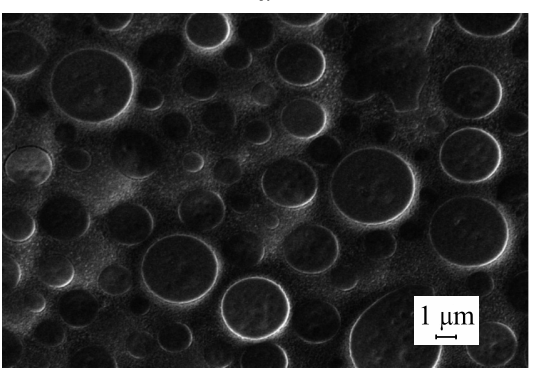

$b$

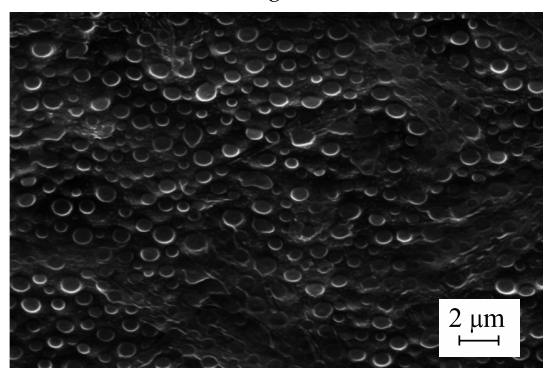

Fig. 7. SEM photos of the Na-CAS - KAN complex particles in the case of direct $(a)$ and inverse $(b)$ order of the components solutions mixing

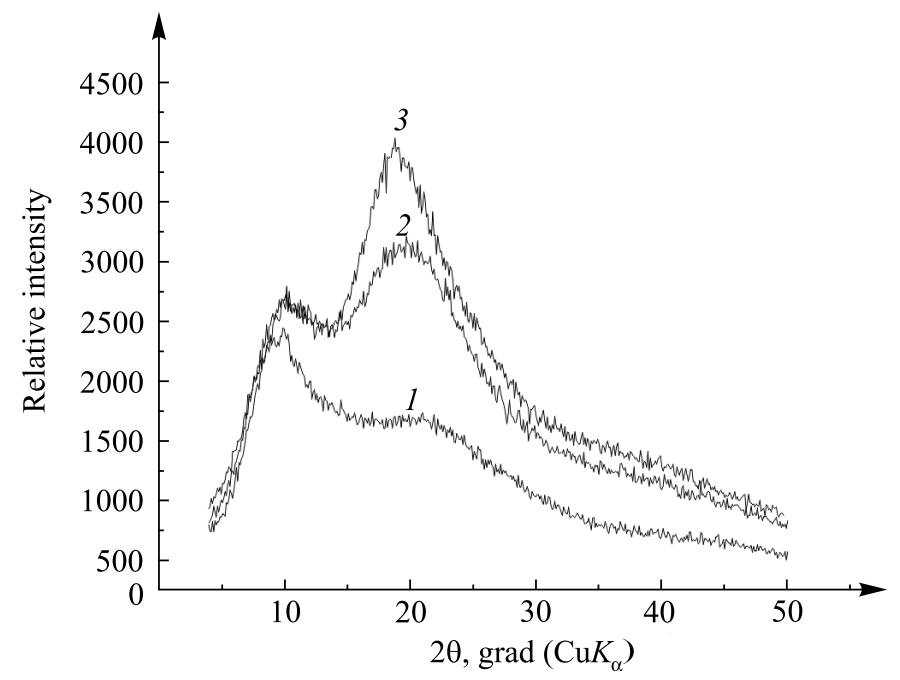

Fig. 8. XRD curves of Na-CAS (1); Na-CAS - KAN complex (2); KAN (3) 
Initial salt form of KAN destroys as a result of complex formation and $\mathrm{AB}$ becomes connected strongly with polymer in the insoluble complex. The complexion is accompanied by the changing in the individual components' bands position in FTIR spectra. As follows from table 6, significant changes take place in the field of hydrogen bonds. According to fig. 8, the structural features of KAN preserves in the complex (curves 2 and 3). To imagine the structure of the complex quantum chemical calculations have been done. Computational studies on KAN are rarer still [9]. Molecular dynamics and docking studies were performed for aminoglycoside monomers and RNA [24; 25], using standard force fields and scoring functions. Apparently only in two cases electronic structure theory methods were applied to KAN: one of them again in the context of KAN binding to RNA, the other one for the isolated monomer in the gas phase [26]. Both studies, however, only employed HF calculations with small basis sets. Theoretical studies on KAN A complexion with cellulose derivative appear to be non-existent. In this work, we performed a quantum-chemical study of the structure and binding energy of the KAN dimer and the Na-CAS - KAN complex. The structures of the lowest energy conformations of the KAN A dimer and the Na-CAS - KAN complex are shown on fig. 9 and 10. The calculated BSSE corrected binding energies of KAN A dimer and KAN - CAS complex are -199 and $-299 \mathrm{~kJ} / \mathrm{mol}$ respectively. This shows that complex formation is an energetically preferable process compared to dimerisation. Figure 10 shows that in KAN-CAS complex KAN molecule is protonated on amino groups at C6' (ring A) and C1 (ring B). This is consistent with the results of our calculation of $\mathrm{pK}_{\mathrm{a}}$ value of KAN A [24], showing that amino group at $\mathrm{C}^{\prime}$ ( ring $\mathrm{A}$ ) is the most basic.

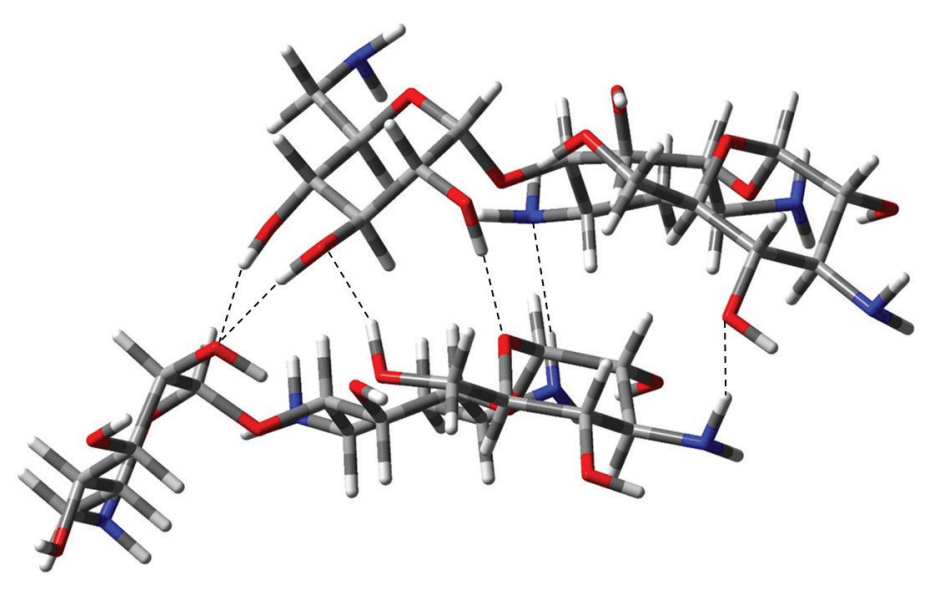

Fig. 9. The structure of the lowest energy conformation of KAN A dimer obtained as a result of conformational search with subsequent geometry optimisation at wB97XD/6-31G(d) level

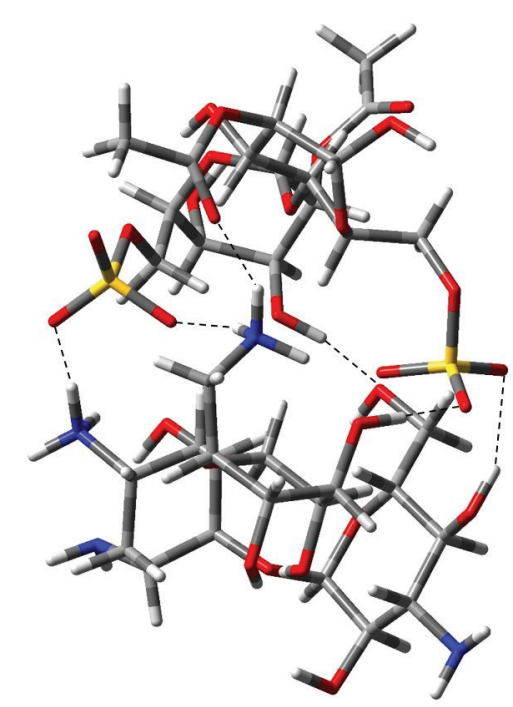

Fig. 10. The structure of the lowest energy conformation of Na-CAS - KAN obtained as a result of conformational search with subsequent geometry optimisation at wB97XD/6-31G(d) level

The involving of polymer and drug functional groups into different kinds of interaction influences on the properties of their complex as opposed to the initial components.

Figure 11 demonstrates DSC, DTG and TG curves for KAN, Na-CAS and their complex in the temperature range up to $400{ }^{\circ} \mathrm{C}$. As can be seen, KAN shows three endothermic peaks. The first broad one corresponds to the water loss, the rest ones can be due to decomposition phenomena [27]. Several peaks appear on the Na-CAS DSC curve: the first endothermic one at $71{ }^{\circ} \mathrm{C}$ corresponds to the evaporation of water molecules. Exothermic processes occurring at the temperature $189 ; 203$ and $216^{\circ} \mathrm{C}$ can be caused, most probably, due to the removal of the sulfuric acid, formed as a result of interaction between two closely located sulphate groups and their hydration [12]. Endothermic peak at $253.1^{\circ} \mathrm{C}$ very likely corresponds to the thermal destruction of sulphate groups meanwhile it shifts to $238.2^{\circ} \mathrm{C}$ at the DSC curve for complex because of these groups participation in the ionic interaction with $\mathrm{AB}$. The shift of $216.0^{\circ} \mathrm{C}$ peak to $228.5^{\circ} \mathrm{C}$ has the same reason. The appearance of $283.4^{\circ} \mathrm{C}$ peak in the DSC profile for the complex provided it's absence for the components confirms their interaction as well. DTG curve for complex has a peak of maximum decomposition rate at $228.5^{\circ} \mathrm{C}$ in the comparison with $216.0^{\circ} \mathrm{C}$ peak for Na-CAS and $256.4{ }^{\circ} \mathrm{C}$ - for KAN.

Taking into account the complex formation between Na-CAS and KAN, the preservation of AB activity has become the subject of the study. Herein, we propose and detail a simple drug delivery design approach, 
exploiting the complexation and adsorption of the complex on the AC, to achieve a sustained and complete release of KAN from GIT to blood. Na-CAS - KAN complexes themselves and immobilised on the AC were tested on the archival strain of M. tuberculosis. As a result, it was established that the KAN complex exhibits twice as many activities of the standard (injection) KAN form (with a minimum inhibiting concentration of $30 \mu \mathrm{g} / \mathrm{cm}^{3}$ ), while the active substance concentration was only $15 \mu \mathrm{g} / \mathrm{cm}^{3}$ (table 7). Figure 12 demonstrates the visual similar effect of tableted form of Na-CAS - KAN complex immobilised on the AC and injection form on the bacterial growth.

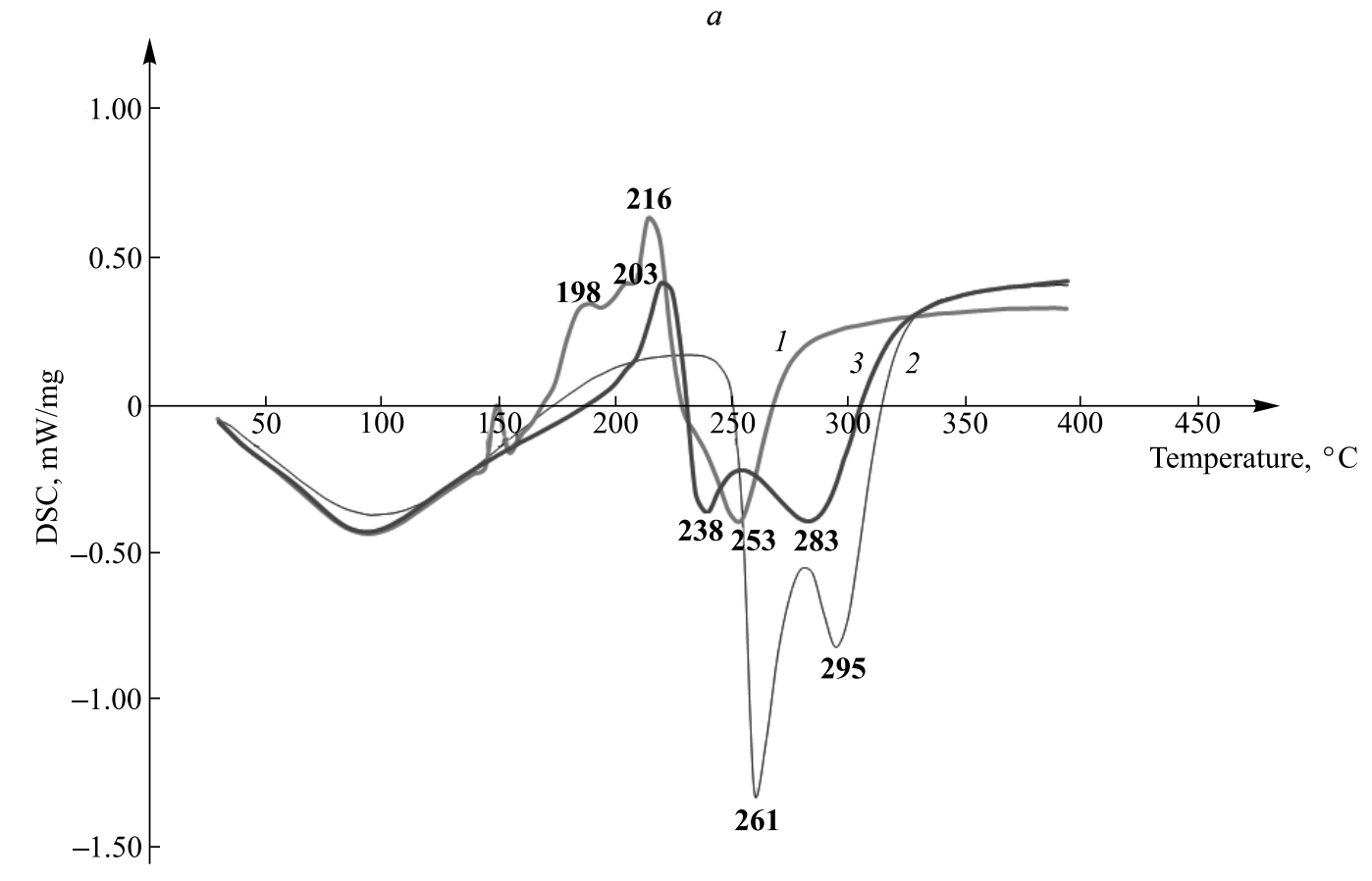

$b$

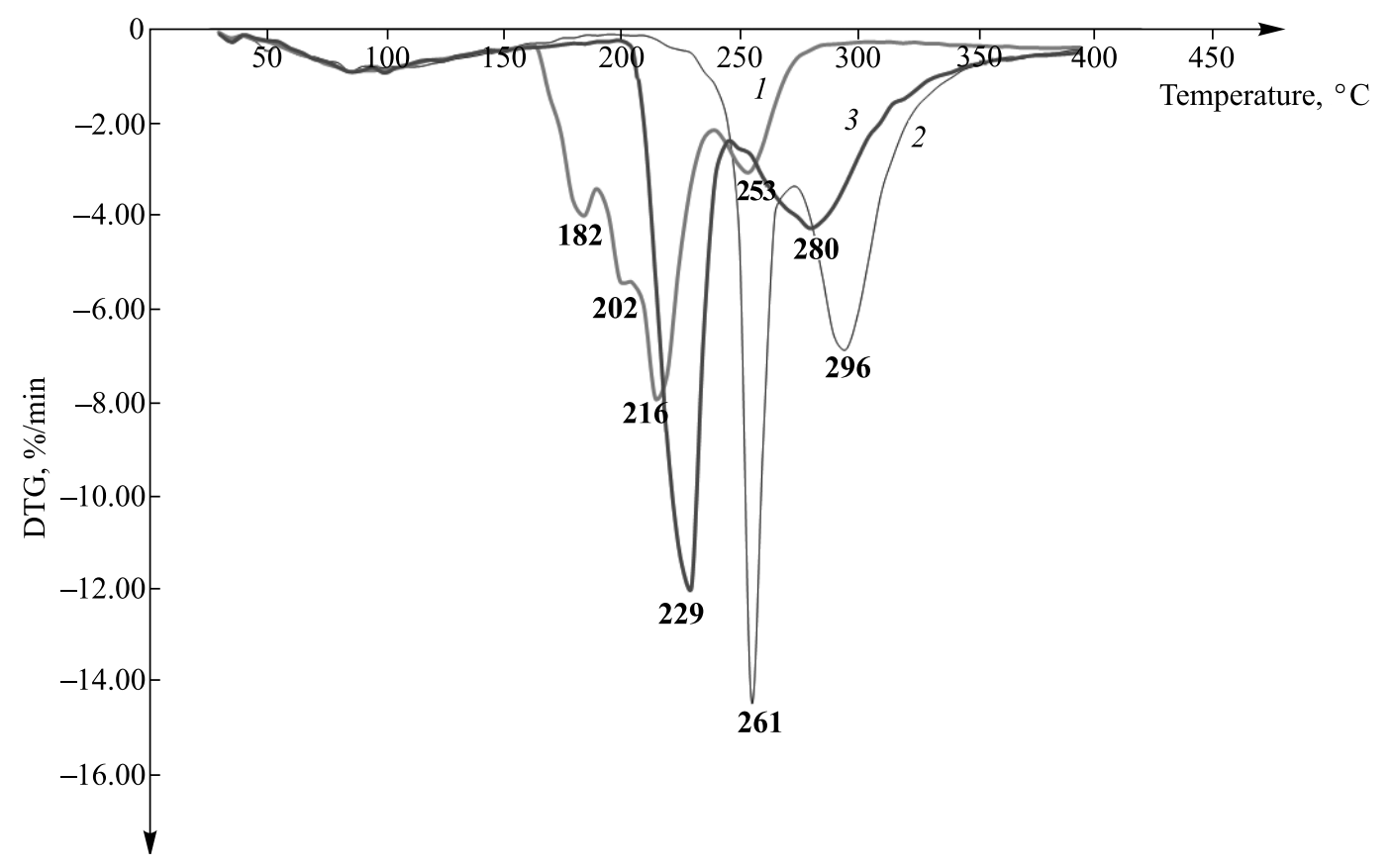

Fig. 11. DSC (a) and DTG (b) curves for Na-CAS (1), KAN (2), Na-CAS - KAN complex (3) 
Estimation of the minimum active dose of KAN in a complex

in the comparison with an injection by the method of absolute concentrations on a solid nutrient medium of Löwenstein - Jensen in vitro

\begin{tabular}{|c|c|c|}
\hline $\begin{array}{c}\text { Antibiotic concentration per } 1 \mathrm{~cm}^{3} \text { of } \\
\text { nutrient medium, } \mu \mathrm{g} / \mathrm{cm}^{3}\end{array}$ & Standard KAN injection form & KAN in a complex with Na-CAS \\
\hline 60 & No growth & No growth \\
\hline 30 & $»$ & $»$ \\
\hline 15 & Moderate growth & $»$ \\
\hline
\end{tabular}

It should be stressed that there is a fresh opinion [28] on the AC may prevent negative effects of $A B$ on the microbiome. AC could solve this problem by allowing antibiotics to kill pathogenic microbes while sparing those that are important to gut health. It does not impact on the amount of drug entering the bloodstream. But it releases slowly the absorbed drug at the large intestine.

An in vivo study of the effectiveness of the combined dosage form of an $\mathrm{AB}$ and $\mathrm{AC}$ showed that the concentration of the antibiotic entering the blood from the tablet dosage form corresponds to its concentration entering the blood from the injection form (fig. 13). Figure 13 confirms almost equal bioavailability of injection and new dosage form of KAN. One can see that an adequate plasma level of KAN is achieved in both cases, when using a similar dose orally or intramuscularly. So, Na-CAS - KAN complex immobilised on the AC is a good carrier for KAN delivery. The concentration of KAN in the blood was determined by agar diffusion test with respect to Bacillus subtilis. A distinctive feature of the tablet form is the prolongation of action.

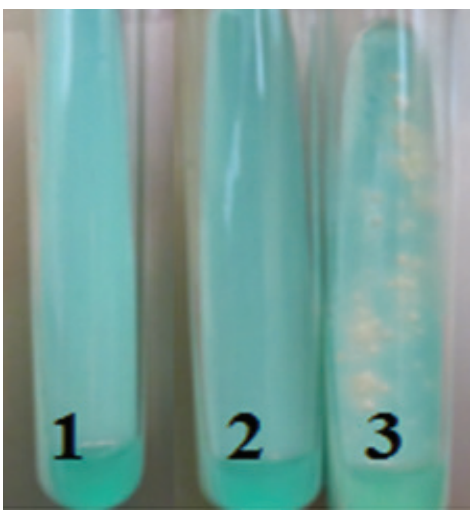

Fig. 12. Bacteriological research of Na-CAS - KAN complex immobilised on the AC in vitro: 1 - inhibition of bacterial growth by the injection form of KAN; $\mathbf{2}$ - suppression of bacterial growth by the AC tablet form of Na-CAS - KAN complex; 3 - bacterial growth in the absence of an AB

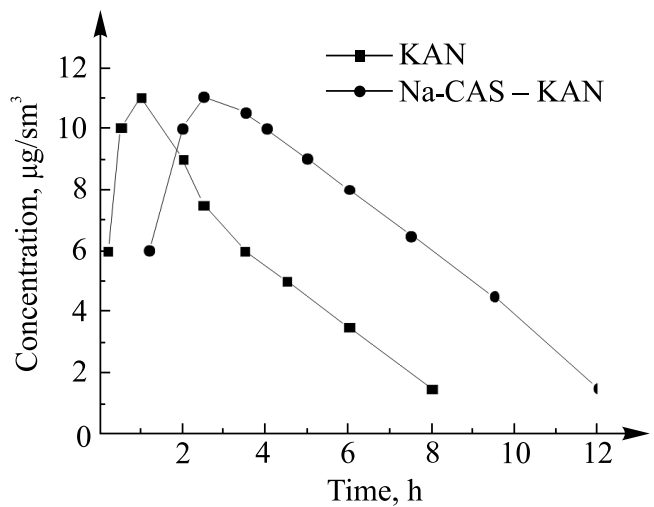

Fig. 13. Kinetics of KAN release into volunteer's blood in vivo from injection KAN dosage form and

Na-CAS - KAN complex immobilised on $\mathrm{AC}$ oral dosage form

The present study enables us to suggest the explanation for the role of polymer in the creation of bioactive oral dosage form of KAN. Oral usage drugs, before they enter the bloodstream and target the bacterial RNA, must penetrate the numerous biological membranes of epithelial and endothelial cells of the GIT and then the bacterial membranes [29]. Molecular properties that are important for the penetration include molecular weight, size, conformation, degree of ionisation, polar surface area, non-polar surface area, lipophilicity and number of $\mathrm{H}-$ bonding acceptors and donors [30].

It is a matter of general experience that hydrophilic ionised drugs transport across biological membranes is poor. They have low oral bioavailability. For KAN it is reported about the increase of permeability by the ionpair transport. But this concept still not extensively used because of the difficult search for specific lipophilic counter ions with a convenient physiological compatibility. It has been shown that at a physiological $\mathrm{pH}$ 7.4, KAN molecules are dimerised [8].

Dimerisation provides the formation of hydrogen bonds between hydroxyl groups of AB molecules. In this case, the amino groups of $\mathrm{AB}$ in the dimer remain free, which does not allow such an ionised aggregate to 
penetrate through the lipid membranes (see fig. 9 and 10). Thus, the ionised AB dimer cannot penetrate through the phospholipid bilayer of the membranes on the one hand, and, on the other hand, it does not have enough free hydroxyl groups for binding with the transporter protein molecule, which could ensure AB transfer by the mechanism of active diffusion through transmembrane protein channels with its subsequent release into the bloodstream from the opposite side of the membrane [31]. Complexion of KAN with Na-CAS increases the lipophilicity of the drug that can change its behaviour in GIT.

In view of the importance of polar and non-polar area distribution on the surface of the drugs influence on their GI absorption, the molecular electrostatic potential (MEP) surfaces were calculated using the B3LYP/6-31G(d, p) basis set [32]. Figures 14-17 illustrate the distribution of the electrostatic potential (EP) values at the surface for KAN monomer, dimer, CAS (cellobiose fragment) and their complex. They are shown by different colours. EP increases in the order red $<$ orange $<$ yellow $<$ green $<$ blue. The negative regions of MEP, which are related the ability interact with electrophilic reagents, are seen as red and yellow colours, the positive regions that are related to the ability to interact with nucleophilic reacgents, are seen as blue colour.

As can be seen from the diagram (see fig. 14), the regions with the largest negative charge are located near to the lone electron pairs of the nitrogen atoms of the amino groups. And oppositely the regions with the largest positive charge are located near to the hydrogens of hydroxyl groups.

There is no principle changing of MEP diagram in the case of KAN A dimer (see fig. 15) but it has more extended regions of intermediary potential.

As can be seen from fig. 17, there are two wide area of the negative EP that looks like an entirely red blob, and the positive EP area as an entirely blue colour blob on the complex KAN - CAS surface. This means a great electronegativity difference and indicates the presence of ionic bonds in the complex along with hydrogen bonds. It may be assumed that this specific localisation of the surface EP will enhances the transporter-dependent permeability of KAN complexed with Na-CAS. Taking into account that in the Na-CAS - KAN complex positively charged - $\mathrm{NH}_{3}^{+}$groups of $\mathrm{AB}$ molecule are associated with negatively charged - $\mathrm{SO}_{4}^{2-}$ groups of polymer (see fig. 10) one can conclude that at the periphery of the complex the number of charged $-\mathrm{NH}_{3}^{+}$groups decreases compared to the KAN dimer or ion pairs of the KAN cation with the sulphate anion. Thus, the binding of KAN molecules to the complex with Na-CAS makes the surface of the KAN molecules less polar to allow their transport through GIT membranes.
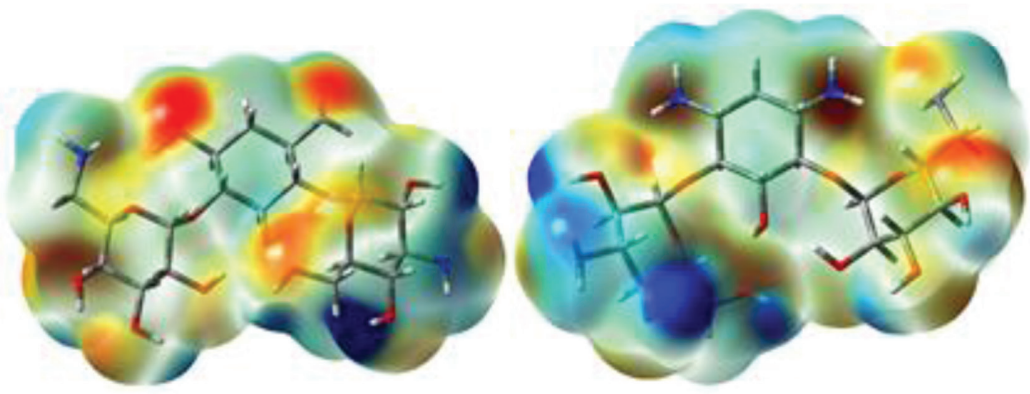

Fig. 14. MEP mapped on a SCF density of KAN monomer
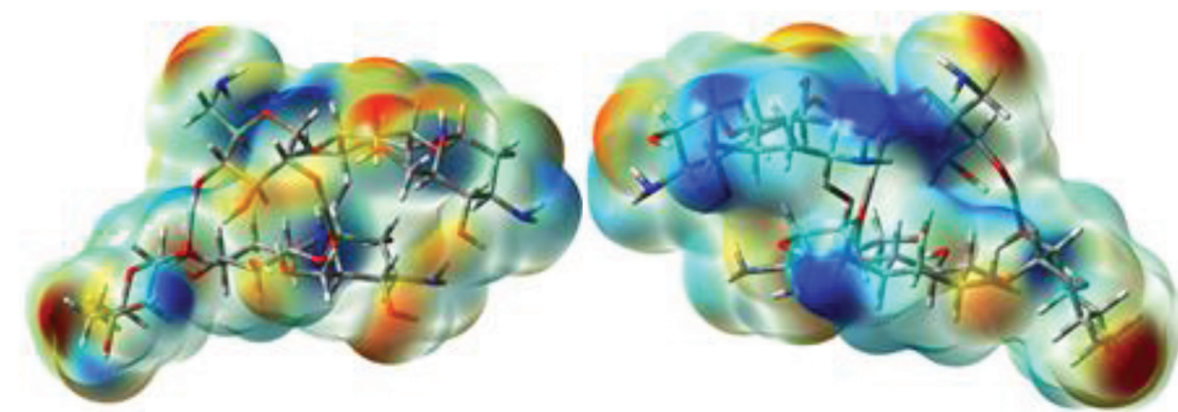

Fig. 15. MEP mapped on a SCF density of KAN A dimer 


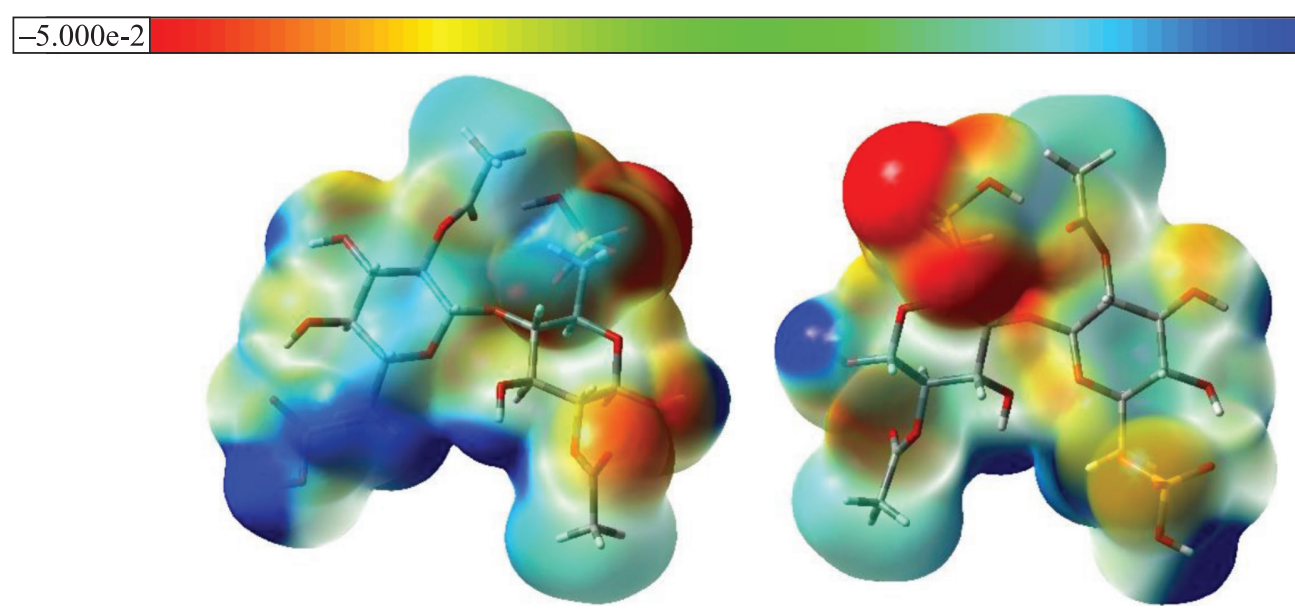

Fig. 16. MEP mapped on a SCF density of CAS (cellobiose fragment)

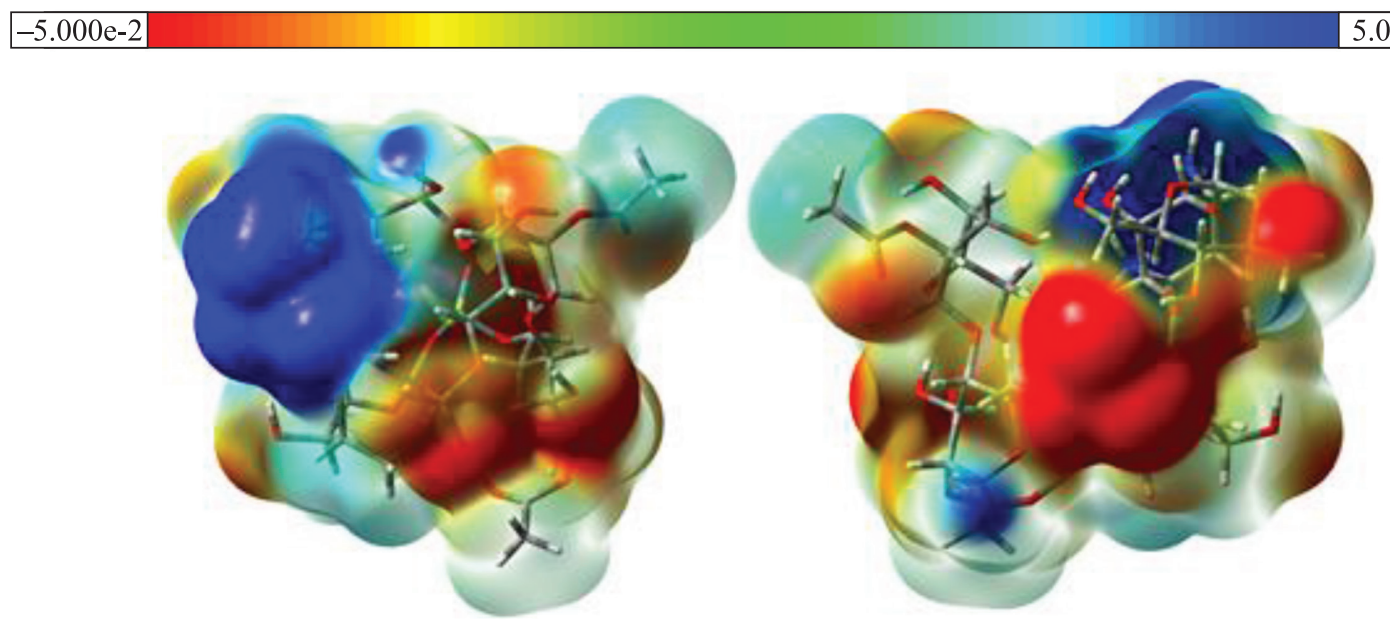

Fig. 17. MEP mapped on an SCF density of complex KAN - CAS

Further investigation will be necessary for the clarification of drug GIT absorption mechanism. For now, we have only the experimental results of the efficacy of ionic drug combination with the electrostatically complementary polyelectrolyte.

\section{Conclusion}

Aminoglycoside antituberculosis AB KAN has been shown to complex with Na-CAS. The composition of resulting hydrophobic product that is generated at $\mathrm{pH} 6.0$ and 7.4 corresponds to molar ratio Na-CAS : KAN that is close to $1.0: 1.0$. Acidification of the solvent leading to the protonation of amino groups increases the amount of Na-CAS mole-links per mole of KAN in the complex till 2.9. The mixing order and the concentration of the components solutions allows to adjust particle size and distribution. Quantum-chemical calculations of the binding energies of KAN - CAS complex and KAN dimer shows that complex formation is an energetically preferable process compared to dimerisation. As a result of the complexation, the rearrangement of intra- and intermolecular bonds both in $\mathrm{AB}$ dimer and Na-CAS cellobiose unit takes place. According to the spectroscopic and thermal analysis data, ionised $\mathrm{NH}_{2}$ groups, which impede the penetration of $\mathrm{AB}$ through the membranes of the epithelial layer, are connected in the complex with sulphate groups by ionic electrostatic interaction along with hydrogen bonds. Additionally, the great electronegativity difference over the complex surface may cause its special interaction with lipid membrane of the GIT walls, making it slightly loose. The hydroxyl groups released from intermolecular hydrogen bonds are able to bind to membrane proteins, which ensures the transport of $\mathrm{AB}$ through the membrane with its subsequent release into the bloodstream from the opposite side of the membrane. Both the hydroxyl and amino functional groups are involved in membrane interaction with the hydroxyl groups being deeper inserted into the membranes. After the disintegration of the complex, the carrier proteins ensure the transfer of $\mathrm{AB}$ monomer through the membrane protein channels. 
A further mechanism of action of KAN is associated with irreversible inhibition of protein synthesis at the level of ribosomes in microorganisms sensitive to them. The monomeric form of $\mathrm{AB}$ is required for binding to the $16 \mathrm{~S}$ site of rRNA. Using of the Na-CAS - KAN complex ensures the delivery of the monomer to the bloodstream, while when using the injection form, bacterium is directly attacked by the KAN dimer, with required preliminary destruction before ribosome attack. It is not yet clear as to what role the absolute configuration of KAN plays apart in this codon - anticodon interaction.

Unquestionably, the mechanism of increasing the activity of the complexes, as compared to individual antibiotics in injections, requires further research. But the results obtained allow us to recommend the polymer salt of KAN with Na-CAS as a new pharmaceutical form for oral administration to the clinical trials with the aim of current injection form replacement.

\section{References}

1. Global tuberculosis report 2018 [Internet]. Geneva: World Health Organization; 2018 [cited 2020 May 15]. 277 p. Available from: https://apps.who.int/iris/bitstream/handle/10665/274453/9789241565646-eng.pdf.

2. Hoppentocht M, Hagedoorn P, Frijlink HW, de Boer AH. Developments and strategies for inhaled antibiotic drugs in tuberculosis therapy: a critical evaluation. European Journal of Pharmaceutics and Biopharmaceutics. 2014;86(1):23-30. DOI: 10.1016/ j.ejpb.2013.10.019.

3. Pignatello R, Leonardi A, Petronio GP. Preparation and microbiological evaluation of amphiphilic kanamycin-lipoamino acid ion-pairs. Antibiotics. 2014;3(2):216-232. DOI: 10.3390/antibiotics3020216.

4. Tarabukina EB, Solovskii MV, Pautov VD, Amirova AI, Zakharova NV, Smirnova MY, et al. Physicochemical, molecular, and biological properties of complexes formed between aminoglycoside antibiotics and some anionic copolymers of acrylic series. Part II. Journal of Bioactive and Compatible Polymers. 2015;30(6):571-583. DOI: 10.1177/0883911515592258.

5. Stebbins ND, Ouimet MA, Uhrich KE. Antibiotic-containing polymers for localized, sustained drug delivery. Advanced Drug Delivery Reviews. 2014;78:77-87. DOI: 10.1016/j.addr.2014.04.006.

6. Mashkovskii MD. Lekarstvennye sredstva [Drug substances (medicinal remedies)]. 13 ${ }^{\text {rd }}$ edition. Khar'kov: Torsing; 1997. 2 volumes. Russian.

7. Francois B, Rupert RJM, Murray JB, Fareed Aboul-ela, Masquida B, Vicens Q, et al. Crystal structures of complexes between aminoglycosides and decoding A site oligonucleotides: role of the number of rings and positive charges in the specific binding leading to miscoding. Nucleic Acids Research. 2005;33(17):5677-5690. DOI: 10.1093/nar/gki862.

8. Dieterich JM, Gerstel U, Schroder J-M, Hartke B. Aggregation of kanamycin A: dimer formation with physiological cations. Journal of Molecular Modeling. 2011;17:3195-3207. DOI: 10.1007/s00894-011-0983-x.

9. Michael K, Wang H, Tor Y. Enhanced RNA binding of dimerized aminoglycosides. Bioorganic \& Medicinal Chemistry. 1999;7(7):1361-1371. DOI: 10.1016/s0968-0896(99)00071-1.

10. Kopaczynska M, Lauer M, Schulz A, Wang T, Schaefer A, Fuhrhop J-H. Aminoglycoside antibiotics aggregate to form starchlike fibers on negatively charged surfaces and on phage $\lambda$-DNA. Langmuir. 2004;20(21):9270-9275. DOI: 10.1021/la049207m.

11. Greenwood D. Antimicrobial drugs: chronicle of a twentieth century medical triumph. Oxford: Oxford University Press; 2008. $429 \mathrm{p}$.

12. Grinshpan DD, Savitskaya TA, Tsygankova NG, Makarevich SE, Tretsiakova SM, Nevar TN. Cellulose acetate sulfate as lyotropic liquid crystalline polyelectrolyte: synthesis, properties, and application. International Journal of Polymer Science. 2010;2010:831658. DOI: https://doi.org/10.1155/2010/831658.

13. French AD. Glucose, not cellobiose, is the repeating unit of cellulose and why that is important. Cellulose. 2017;24(11): 4605-4609. DOI: 10.1007/s10570-017-1450-3.

14. Mikkelsen LH. Applications and limitations of the colloid titration method for measuring activated sludge surface charges. Water Research. 2003;37(10):2458-2466. DOI: 10.1016/S0043-1354(03)00021-6.

15. World Health Organization. Laboratory services in tuberculosis control. Part III. Culture [Internet]. Geneva: World Health Organization; 1998 [cited 2020 May 15]. 97 p. Available from: https://apps.who.int/iris/bitstream/handle/10665/65942/WHO_ TB $98.258 \% 28$ part3\%29.pdf? sequence $=3$ \&isAllowed $=$ y.

16. Yanai T, Tew DP, Handy NC. A new hybrid exchange - correlation functional using the coulomb-attenuating method (CAM-B3LYP). Chemical Physics Letters. 2004;393(1-3):51-57. DOI: 10.1016/j.cplett.2004.06.011.

17. Gaponik PN, Voitekhovich SV, Lyakhov AS, Matulis Vadim E, Ivashkevich OA, Quesada M, et al. Crystal structure and physical properties of the new $2 \mathrm{~d}$ polymeric compound bis(1,5-diaminotetrazole)dichlorocopper(II). Inorganica Chimica Acta. 2005;358(8):2549-2557. DOI: 10.1016/j.ica.2005.03.005.

18. Cances E, Mennucci B, Tomasi J. A new integral equation formalism for the polarizable continuum model: theoretical background and applications to isotropic and anisotropic dielectrics. Journal of Chemical Physics. 1997;107(8):3032-3041. DOI: $10.1063 / 1.474659$.

19. Perrin DD. Dissociation constants of organic bases in aqueous solution: supplement. London: Butterworths; 1972.473 p.

20. Voitekhovich SV, Lyakhov AS, Matulis VE, Ivashkevich LS, Ivashkevich OA. Substituent-dependent coordination modes of 1-methyl-5-R-tetrazoles in their cupric chloride complexes. Polyhedron. 2019;162:100-110. DOI: 10.1016/j.poly.2019.01.009.

21. Bannwarth C, Ehlert S, Grimme S. GFN2-xTB - An accurate and broadly parametrized self-consistent tight-binding quantum chemical method with multipole electrostatics and density-dependent dispersion contributions. Journal of Chemical Theory and Computation. 2019;15(3):1652-1671. DOI: 10.1021/acs.jctc.8b01176.

22. Grimme S, Brandenburg JG, Bannwarth C, Hansen A. Consistent structures and interactions by density functional theory with small atomic orbital basis sets. Journal of Chemical Physics. 2015;143(5):054107. DOI: 10.1063/1.4927476.

23. Fuentes-Martínez Y, Godoy-Alcántar C, Medrano F, Dikiy A, Yatsimirsky AK. Protonation of kanamycin A: detailing of thermodynamics and protonation sites assignment. Bioorganic Chemistry. 2010;38(4):173-180. DOI: 10.1016/j.bioorg.2010.04.003. 
24. Hermann T, Westhof E. Docking of cationic antibiotics to negatively charged pockets in RNA fold. Medicinal Chemistry. 1999;42(7):1250-1261. DOI: 10.1021/jm981108g.

25. Moitessier N, Westhof E, Hanessian S. Docking of aminoglycosides to hydrated and flexible RNA. Medicinal Chemistry. 2006;49(3):1023-1033. DOI: 10.1021/jm0508437.

26. Monajjemi M, Heshmata M, Haeria HH. QM/MM model study on properties and structure of some antibiotics in gas phase: comparison of energy and NMR chemical shift. Biochemistry (Moscow). 2006;71(1, supplement):S113-S122. DOI: 10.1134/ S0006297906130190.

27. López-Cervantes M, Escobar-Chávez JJ, Casas-Alancaster N, Quintanar-Guerrero D, Ganem-Quintanar A. Development and characterization of a transdermal patch and an emulgel containing kanamycin intended to be used in the treatment of mycetoma caused by Actinomadura madurae. Drug Development and Industrial Pharmacy. 2009;35(12):1511-1521. DOI: 10.3109/03639040903037215.

28. Gunzburg JDe, Ghozlane A, Ducher A, Chatelier ELe, Duval X, Ruppé E, et al. Protection of the human gut microbiome from antibiotics. Journal of Infectious Diseases. 2018;217(4):628-636. DOI: 10.1093/infdis/jix604.

29. John T, Thomas T, Abel B, Wood BR, Chalmers DK, Martin LL. How kanamycin A interacts with bacterial and mammalian mimetic membranes. Biochimica et Biophysica Acta (BBA) - Biomembranes. 2017;1859(11):2242-2252. DOI: 10.1016/j.bbamem.2017.08.016.

30. Fagerholm U. Prediction of human pharmacokinetics - gastrointestinal absorption. Journal of Pharmacy and Pharmacology. 2007;59(7):905-916. DOI: 10.1211/jpp.59.7.0001

31. Stein WD. Transport and diffusion across cell membranes. New York: Academic Press; 1985. 704 p. DOI: 10.1016/B978-012-664660-3.X5001-7.

32. Akman F. Prediction of chemical reactivity of cellulose and chitosan based on density functional theory. Cellulose Chemistry and Technology. 2017;51(3-4):253-262. 